Democracy and the Origins of the American Regulatory State 
The Institution for Social and Policy Studies at Yale University The Yale ISPS Series 


\section{Democracy and the Origins of the}

\section{American}

\section{Regulatory State}

Samuel DeCanio

Yale UnIVERSITY PRESS

NEW HAVEN AND LONDON 
Published with assistance from the Louis Stern Memorial Fund.

Copyright (C) 2015 by Samuel DeCanio.

All rights reserved.

This book may not be reproduced, in whole or in part, including illustrations, in any form (beyond that copying permitted by Sections 107 and Io8 of the U.S. Copyright Law and except by reviewers for the public press), without written permission from the publishers.

Yale University Press books may be purchased in quantity for educational, business, or promotional use. For information, please e-mail sales.press@yale.edu (U.S. office) or sales@yaleup.co.uk (U.K. office).

Set in Adobe Garamond type by Newgen North America.

Printed in the United States of America.

Library of Congress Control Number: 2015933606

ISBN 978-0-300-19878-2 (pbk: alk. paper)

A catalogue record for this book is available from the British Library.

This paper meets the requirements of ANSI/NIsO Z39.48-I992 (Permanence of Paper).

IO 98765432 I 
For my father 
This page intentionally left blank 